Volume 13

Number 12013

Article 4

December 2013

\title{
End of Life and Saving Souls: Should a Desire for Converts Influence End-of-life Ethics?
}

Michelle E. Frazer

Cedarville University, mfrazer@cedarville.edu

DigitalCommons@Cedarville provides a publication platform for fully open access journals, which means that all articles are available on the Internet to all users immediately upon publication. However, the opinions and sentiments expressed by the authors of articles published in our journals do not necessarily indicate the endorsement or reflect the views of DigitalCommons@Cedarville, the Centennial Library, or Cedarville University and its employees. The authors are solely responsible for the content of their work. Please address questions to dc@cedarville.edu.

\section{Recommended Citation}

Frazer, Michelle E. (2013) "End of Life and Saving Souls: Should a Desire for Converts Influence End-of-life Ethics?," CedarEthics: A Journal of Critical Thinking in Bioethics: Vol. 13 : No. 1 , Article 4.

DOI: $10.15385 /$ jce.2013.13.1.4

Available at: http://digitalcommons.cedarville.edu/cedarethics/vol13/iss1/4 


\title{
End of Life and Saving Souls: Should a Desire for Converts Influence End- of-life Ethics?
}

Browse the contents of this issue of CedarEthics: A Journal of Critical Thinking in Bioethics.

\begin{abstract}
In 1 Timothy 2:3, Paul states "God our Savior... wants all people to be saved and to come to a knowledge of the truth" (NIV). In keeping with God's desire for the salvation of all, Christians should work towards that goal. From an evangelical Christian perspective, upon death, the status of one's soul is fixed, bound either for heaven or hell.

This perspective should deeply influence our interactions with unbelievers, not only encouraging us to share the gospel, but also giving us an incentive to delay their physical death. Indeed, according to 2 Peter 3:9, the reason God is delaying the final consummation of all things is because "he is patient with you, not wanting anyone to perish, but everyone to come to repentance." Similarly, Christians should desire to avoid taking away an individual's chance at salvation. This argument can be a powerful (though not necessarily alltrumping) argument against killing, often used in the context of pacifist or anti-death penalty argumentation, but I contend this argument is also an important consideration for end-of-life ethics in a medical context.
\end{abstract}

\section{Keywords}

End of life, salvation

\section{Creative Commons License} (c) $($ ) () ()

This work is licensed under a Creative Commons Attribution-Noncommercial-No Derivative Works 3.0 License.

Follow this and additional works at: http://digitalcommons.cedarville.edu/cedarethics

Part of the Bioethics and Medical Ethics Commons, and the Ethics in Religion Commons 


\title{
End of Life and Saving Souls: Should a Desire for Converts Influence End-of-life Ethics?
}

\author{
Michelle E. Frazer \\ Cedarville University
}

I n 1 Timothy 2:3, Paul states "God our Savior... wants all people to be saved and to come to a knowledge of the truth" (NIV). In keeping with God's desire for the salvation of all, Christians should work towards that goal. From an evangelical Christian perspective, upon death, the status of one's soul is fixed, bound either for heaven or hell.

This perspective should deeply influence our interactions with unbelievers, not only encouraging us to share the gospel, but also giving us an incentive to delay their physical death. Indeed, according to 2 Peter 3:9, the reason God is delaying the final consummation of all things is because "he is patient with you, not wanting anyone to perish, but everyone to come to repentance." Similarly, Christians should desire to avoid taking away an individual's chance at salvation. This argument can be a powerful (though not necessarily all-trumping) argument against killing, often used in the context of pacifist or anti-death penalty argumentation, but I contend this argument is also an important consideration for end-of-life ethics in a medical context.

Naturally, the hope of salvation of a non-believer might be a consideration in not wanting a fully conscious person to commit suicide or to be euthanized. But what about one who is not conscious? The question at stake, then, is does a person have hope of salvation right up until the moment of death (as defined by standard clinical criteria, that is, cessation of all brain or cardiopulmonary activity), or does that hope disappear earlier? In addressing this question, I am working from the assumption that there is no chance of salvation after death. Therefore, the issue becomes the following question: "When can a person no longer communicate with God?" For example, can an individual in a permanent vegetative state (PVS) who presumably has no autonomous brain function, still communicate with the divine? Assuming no chance of recovery from PVS, does allowing one in PVS to die (say by starvation), interfere with the possibility of a change in his or her eternal destination?

\section{Background}

These questions are extremely difficult to answer because they embody so many other philosophical, ethical, and biblical debates. One in particular, the relationship between mind and brain, is critical. Are higher functions of human thought (the mind) due to activity of the physical human brain? Communication with God would seem to be a function of the mind. Is it therefore

a function of the brain as well? Individuals in PVS still have brain functions as they react reflexively and even have sleep/wake cycles. But these activities are functions of only the brain stem, so if the mind is part of one of the higher-level thinking parts of the brain, then the mind is no longer active. That is, unless the mind is completely separate from the brain, perhaps part of a 
person's soul, distinct from the body. After all, it would seem that the human possession of soul is what grants us the capacity to communicate with God (unlike animals). Could soul and body be separate to the extent that one could somehow communicate with God through the soul without the use of the body?

Therefore, in order to discuss the impact that a Christian hope of salvation for all should have on end-of-life ethics, I will focus on one particular case: a person in PVS. I will first discuss differing views on the relationship between mind and brain, next discuss implications for how one communicates with God and is converted, and finally draw conclusions on the salvationpotential of an individual in PVS. In doing so, I will operate from the following assumptions: (1) the individual in PVS is not yet dead, (2) the individual in PVS has been correctly diagnosed; that is, there is no hope of recovery from the vegetative state, and (3) once dead, there is theologically no "second chance" for the individual to be saved. Additionally, I will approach this topic from what I believe to be the clear Christian perspective that humans are more than just a physical body, but also possess something higher, what we call a "soul," though the exact relationship between soul and body is debatable. I will conclude with a discussion on how the desire for converts should influence the Christian's approach to end-of-life ethics, not just involving the PVS patient, and not simply restricted to these assumptions.

\section{Brain and Mind: Three Views}

To answer the question of how God communicates to humans, it first important to understand the distinction (if any) between mind and brain. Andrew Newburg attempts to clarify the debate by providing the following definitions:

Brain: This will refer to the structure of cells, molecules, and connections in the organ inside the head. This will include the neocortex, the subcortical structures, limbic system, hypothalamus, cerebellum and brainstem....

Mind: This will refer to the subjectively experienced functions that arise from the brain including our thoughts, feelings, and perceptions... It will also be understood that while many aspects of the mind might be considered to be specifically caused by the brain there may be (emphasis on "may") mind processes that exist beyond the brain particularly in the form of consciousness of subjective awareness. (2010, p. 47)

In other words, the brain is a physical structure, while the mind is subjectively experienced functions whose connection to the brain is subject to debate. Hence, I will discuss three areas of thought on the relationship between brain and mind, ranging from the idea that that important aspects of consciousness are entirely distinct from the brain to the idea no mind processes exist beyond the brain. 


\section{View 1: Mind beyond Brain: Cartesian Dualism}

This view holds that some, or all, or the functions of the mind are entirely independent of the physical brain. Christianity tends to think of the human being more than brain and body, as having some type of "soul," so this view can be rather attractive. An extreme dualist view, championed by Rene Descartes, is that mind and body are split (McPhate, 2010).

Descartes argued that since he knew he was a substance, he must be able to think solely by the soul, distinct from the body. His soul (which included all the functions defined above as part of the mind) constituted his personhood, regardless of whether his body existed, hence his famous phrase, "I think therefore, I am."

Holding to such a drastic dualist view would certainly have implications for end-of-life ethics. A PVS patient, while having lost much bodily functioning, would not have lost any aspect of his or her soul and therefore the ability to perform higher thinking functions such as self- awareness. It is also possible to reject extreme Cartesian dualism while holding that there are still some aspects of the mind which exist beyond the body. Christians, especially, may believe that much of the activity included in the definition of mind (such as thinking, self-awareness, and perceiving) does make use of the physical structure of the brain, but there are some functions which exist beyond the brain. Perhaps communicating with God and conversion experiences are something special, a direct communication between God and the human soul, without the conduit of the body.

\section{View 2: Mind through Brain: Substance Dualism}

A less extreme variant of this view is that the mind, through the soul, is beyond the brain in that it is separate and possesses different properties. Yet, there is still a connection between the two. This view is consistent with the substance dualist view of body soul, championed in the modern Christian circle by philosopher J. P. Moreland, who explains the implications for mind and brain: "The soul is the possessor of its experiences. It stands behind, over, and above them.... The soul and the brain can interact with each other, but they are different entities with different properties" (1993, p. 61).

Thus, mind, associated with the soul, is separate and above the brain. Yet, it functions by using the brain as a sort of tool, interacting with the physical structures of the brain. This functioning would include structures other than simply the brain stem, so a PVS patient would lack the physical capabilities to support a life of the mind and therefore a life of the soul. This conclusion does not imply that the patient is in fact dead or no longer a person. By the substance dualist view, they still possess the intrinsic essence of being human.

\section{View 3: Mind from Brain: Physicalism or Property Dualism}

This view goes beyond saying that the mind and brain interact to claiming that the mind is no more than a product or function of the brain. The secular version of this view is expressed well by neuroscientist Michael Graziano "...the experience of self, soul, consciousness, spirit, god, everything that populates the spiritual world, is a perception of mind and is created by the social 
machinery of the brain" (2010, p. 16). Such thought often corresponds with a search for a "godspot" in the brain, an area of the brain that is wired to produce thoughts of the divine. By suggesting that the seemingly un-physical is really just a product of the physical, this view is clearly consistent with physicalism.

But, a form of dualism also holds to a variant of this view, suggesting that the mind is a function or tool of the brain. Under "property dualism," as J. P. Moreland explains, "The brain is the possessor of all mental properties... I am a brain and a series or bundle of successive experiences themselves" (1993, p. 60). The clear implication of both variants of the view that the mind comes from the brain is that a PVS patient, having lost autonomous brain function, has lost all mind function as well.

To summarize, one must hold to a version of extreme dualism such as Cartesian dualism to believe than mind functions can continue after brain function has ceased, as in the case of the PVS patient (none from the other views claim that the mind can operate solely through the brain stem). Even if the mind is higher than the brain, as in the substance dualist view, the brain still is required for mental activity.

\section{How then Do God and Humans Communicate?}

Clearly, then, one's view of the relationship between mind and brain has implications for the salvation potential of a PVS patient. Before I can weigh judgment on this subject, I must first establish what I believe is a proper understanding for mind and brain and what therefore human interaction with God (communication and conversion) looks like. I would argue that communication with God is more than physical firing of neurons (a rejection of the third view of mind and body), and yet requires the interaction with the brain (a rejection of the first view). Specifically, conversion is an embodied experience which therefore has a physical aspect.

\section{Communication with God is More than Brain}

Even from a secular perspective, it is difficult to reduce the mind to just brain activity. C. S. Lewis provides a simple, but persuasive argument: "The theory that thought therefore is merely a movement in the brain is, in my opinion, nonsense, for if so, that theory itself would be merely a movement... of which it would be meaningless to use the words 'true' or 'false'" (2001, p. 103). Logically, the way we think and speak about the mind and our thought processes is difficult to reconcile with a physicalist interpretation of the brain.

From a Christian standpoint, it is even harder to reduce our thoughts about God to just movement in the brain. Sybod (2005) discusses this in reference to the popular talk of a 'God- spot' in the brain: "To suggest, however, that God is located in the brain is no more acceptable that [sic] to say that my enjoyment of sailing is located in a 'Sailing Spot.' ... Religious experience, like most human experience, is irreducible and nonreductive" (p. 128). Communication with God, like most high forms of brain activity, cannot be adequately described by deterministic physicalism. If there is no higher control to thought than the firing of neurons in the brain, how can humanity be said to have free will? 


\section{Communication with God Involves the Brain}

Christians tend to use the language of soul to describe the notion that there is something more to being human than simply possessing a body and a brain (McPhate, 2010), but it is possible to get too carried away with the idea of soul. A consistent theme of Scripture is that God works through our physicality to communicate with us. After all, God himself at the incarnation took on human flesh and operated through a bodily existence. But is it possible for some of the highest forms of religious communication or experience to be beyond the body? Malcom Jeeves thinks this type of experience is unlikely: "It is hard to think of any religious activity, however extraordinary (like vision or trances) occurring without accompanying brain activity" (Jeeves, 2013). How could we perceive communication without neural activity?

The growing science of neurotheology (which includes attempts to map the brain to determine what takes place during such religious activity as prayer and meditation) seems to support this conclusion. In 2009, Fingelkurts and Fingelkurts published an extensive review on neurotheology with over 400 references. Their conclusion? "Thus, religious experience does not involve a specific neural system and probably requires joint activation of a family of systems each of which is usually involved in nonreligious contexts" (p. 301). If religious experience requires vast connected brain activity, this would seem to be unavailable to the PVS patient.

Communication with God, then, is best understood in terms of a substance dualist view of mind and body. Our mind is above the brain, and contains its own experiences. God communicates with our mind, using the physical structures of our brain. Accordingly, we utilize our brain to form thoughts and communicate in return.

\section{Conversion is Embodied}

But what about conversion? Is there an exception here? After all, neuroscientists surely cannot map precisely where (or even if) conversion occurs in the brain. I believe there is no exception for conversion. As conversion must take place before death, while humans are both body and soul, it is difficult to imagine how conversion cannot require some element of physicality. If no more than the soul is converted, then why need death be an end to the possibility of conversion?

Theologian Joel Green writes at length about what he calls "embodied conversion." Conversion requires a function of the brain: "Without reducing conversion to neurobiology, we can nonetheless recognize that conversion involves neurobiological transformation" (2008, p. 115). Ultimately, conversion should involve the whole person, mandating a change of lifestyle, not just a change of heart. And yet, I would not deny that a dying individual on their sickbed can be converted, even though they do not have a chance to live out their conversion. Thus, what seems to be at the heart of conversion is a new state of mind that would lead to action, if given the opportunity. Green examines in detail the stories of conversion in the Luke-Acts account, noting how both Greeks and Jews are called to embrace "a new conceptual scheme" (2008, p. 127), that is, "a new way of viewing the world." Conceiving and viewing the world differently requires awareness of the world and cognitive activity of which a PVS patient is not capable.

Moreland and Rae (2000) champion the idea that a PVS patient is still a person, believing that 
drawing distinction between humans and persons is dangerous. To say otherwise is to hold to a functional view of personhood, emphasizing consciousness as a critical function. And yet, apparently, possessing personhood does not necessarily imply the ability to have an active relationship with God. Moreland and Rae (2000) extensively critique Robert Wennberg's position on the loss of personhood with permanent loss of conscious, but do not disagree with Wennberg's statement that, with loss of consciousness, an individual loses the "capacity to shape an eternal destiny by means of decision-making and soul-making" (as cited in Moreland \& Rae, 2000, p. 333). Their analysis is typical of the Christian literature on end-of-life ethics with regard to PVS patients. While Christian ethicists disagree on whether the PVS patient should be kept alive no matter what, or whether he or she is even a person, the assumption is that the opportunity of religious activity and response to God has been lost with the loss of higher brain function.

\section{Conclusion: The implication for End-of-Life Ethics}

Rejecting a Cartesian dualist view of mind beyond brain as well as a physicalist or property dualist view of mind from brain, I believe the best way to understand the interplay of mind and brain is substance dualism. Mind is separate from the brain, but functions through it.

Accordingly, communication with God and religious experience in general requires the function of the brain, as supported by philosophical, neurotheological, and biblical arguments. Conversion, specifically, clearly has an aspect of physicality, as it involves changing of view of the world.

As stated previously, I strongly believe that desire for salvation for all is an important consideration on the side of opposition to physician-assisted suicide and euthanasia. In these cases, it would be unloving to the unsaved patient to end their temporal suffering by seeing them subjected to eternal suffering. However, in light of the reasons presented above, I do not believe that desire for an extended chance of salvation has weight in the debate over continuance of the life of a PVS patient, unless, of course, my starting assumptions are wrong. For example, how certain are we of PVS diagnosis? Should we therefore work to keep PVS patients alive, just in case? I believe that in light of medical research, this approach is probably unnecessary.

In general, Christian physicians and ethical decision-makers ought to keep in mind the broader picture of end-of-life ethics. Meilaender sets out a straightforward and relatively noncontroversial view of end-of-life ethics of denying treatment. We should not aim at, or choose, death, yet, allowing one to die by withholding treatment is permitted. "[Continued life] is not a god, but a gift of God." (2013, p. 69).

Treating extended life as the highest goal is dangerous. Meilaender (2013) uses the example of morphine dosage to demonstrate this idea. A dying patient in great pain might request increased dosage of morphine, yet increased dosage might possibly bring death about more quickly. Can a Christian therefore not administer morphine because of the chance it might kill? This type of reasoning could lead to never administering any type of relief that possibly could have adverse consequences. Also, what type of witness would it be for a Christian doctor to deny the relief of pain because of a desire to prolong life as long as possible? 
The motivation for extending the life of an individual in order to allow them a longer chance for repentance and conversion should, like all other Christian motivations, be considered in balance with other Christian motivations. Nonetheless, Christian physicians, ethicists, and policy-makers as well as any involved in making end-of-life decisions, should not ignore the hope for change of an unsaved person's eternal state.

\section{References}

Fingelkurts, A. A. \& Fingelkurts, A. A. (2009). Is our brain hardwired to produce God, or is our brain hardwired to perceive God? A systematic review on the role of the brain in mediating religious experience. Cognitive Processing, 10, 293-326, doi:10.1007/s10339009-0261-3.

Graziano, M. S. A. (2010). God, soul, mind, brain. Teaticket, MA: Leapfrop Press LLC.

Green, J. B. (2008). Body, soul, and human life: The nature of humanity in the Bible. Grand Rapids, MI: Baker Academic.

Jeeves, M. (2013). Minds, brains, souls, and gods. Downers Grove, IL: InterVarsity Press.

Lewis, C. S. (2001). Transposition. In The weight of glory: And other addresses (pp. 91 - 115). New York, NY: HarperCollins Publishers.

McPhate, G. (2010). Ensoulment revised in response to genetics, neuroscience and out-of-body experiences. In C. Deane-Drummond \& P. M. Scott (Eds.), Future perfect?: God, medicine and human identity (pp. 100-112), New York, NY: T\&T Clark.

Meilaender, G. (2013). Bioethics: A primer for Christians (3rd ed.). Grand Rapids, MI: Wm. B. Eerdmans Publishing Co.

Moreland, J. P. (1993). A defense of a substance dualist view of the soul. In J. P. Moreland \& D. M. Ciocchi (Eds.), Christian perspectives on being human: a multidisciplinary approach to integration (pp. 55-85), Grand Rapids, MI: Baker Book House Company.

Moreland, J.P. \& Rae, S. B. (2000). Body \& soul: Human nature \& the crisis in ethics. Downers Grove, IL: InterVarsity Press.

Newberg, A. B. (2010). Principles of neurotheology. Surrey, England: Ashgate Publishing Limited.

Seybold, K. S. (2005). God and the brain: Neuroscience looks at religion. Journal of Psychology \& Christianity, 24(2), 122-129. 